\title{
Effect of short term infection of Paradactylogyrus catlaius on selected haematological and non-specific immune parameters in Catla catla (Hamilton, 1822)
}

\author{
NIBEDITA RANA AND BASANTA K. DAS \\ Fish Health Management Division, ICAR-Central Institute of Freshwater Aquaculture, Bhubaneswar - 751002 \\ Odisha, India \\ e-mail:basantadas@yahoo.com
}

\begin{abstract}
A short term (20 days) cohabitation infection study of the gill fluke Paradactylogyrus catlaius infecting Catla catla was conducted to investigate on the mode, intensity and effect of infection on selected haematological, immunological and serum biochemical parameters in the infected fish. The results revealed that the increase in the number of parasites is rampant and increased to $161 \pm 23$ parasites per gill lamella in just 20 days post-challenge. Further, significant decrease $(\mathrm{p} \leq 0.05)$ in haemoglobin $(\mathrm{Hb})$, total erythrocyte count $(\mathrm{TEC})$, lysozyme activity, bactericidal activity, total protein and albumin content was noticed whereas a significant increase in total leucocyte count (TLC) was recorded. Globulin content and superoxide anion production increased significantly initially and then decreased $(p \leq 0.05)$. From this study, it was found that $P$. catlaius infection causes no mortality in catla till the $20^{\text {th }}$ day of challenge but the infection can spread to the whole population of catla in short time. Further, it was also observed that the infection can adversely affect the physiological and immunological status of the infected fish. Therefore, appropriate management and control strategies need to be formulated to prevent its spread and to avoid production loss.
\end{abstract}

Keywords: Catla catla, Infection rate, Non-specific immune response, Paradactylogyrus catlaius

\section{Introduction}

Indian freshwater aquaculture contributes to over $95 \%$ of the total aquaculture production where the three Indian major carps (IMC) namely catla (Catla catla), rohu (Labeo rohita) and mrigal (Cirrhinus mrigala) contribute $70-75 \%$ of total freshwater fish production. An increase in the density of these cultured fishes would enable increased production, but high population density leads to incidence of many diseases, of which the parasitic infestations cause significant loss of fish and reduce their growth rate. Little has been explored on the immune status of these species against monogeneans. Many cells (leucocytes, non-specific cytotoxic cells, eosinophilic granular cells, macrophages and other cells) and their products (superoxides, acute phase proteins, lysozymes and agglutinins) contribute to the general immunological defence mechanism in fishes. These have been used as indicators of stress response and disease resistance in fishes (Sahoo and Mukherjee, 2003).

Aquaculture conditions generally result in an increase in parasite populations. Most parasite species rarely cause problems in the natural environment, but under culture conditions can become pathogenic, sometimes causing serious epizootic outbreaks, especially in intensive fish culture. Development of aquaculture has resulted in much greater attention to problems posed by parasites (Kennedy, 1994). The most important parasitic problem reported in captive cyprinid fishes is the infestation with the gill monogeneans. One such monogenetic trematode parasite is Paradactylogyrus catlaius, specifically infecting Catla catla of eastern India (Rana, 2015). Only very little studies have been conducted on Paradactylogyrus which has been proved to be a potential threat for carp culture in eastern India causing mass mortality in catla in many parts of Odisha, West Bengal and Andhra Pradesh.

Paradactylogyrus catlaius was described by Thapar (1948) and its morphology has been described by Yamaguti (1961). They are gill parasites and are highly specific to $C$. catla. The parasites attach to host gill by special attachment organs called opisthaptor which is positioned posteriorly on their body (Park, 2007). $P$. catlaius causing disease in catla has also been identified by $28 \mathrm{~S}$ rDNA sequencing (Rana and Das, 2014). They feed on the blood and mucus of the host, which can place significant stress on the fish's body and can cause secondary infections (Rana, 2015).

The present study of short term infection for 20 days was carried out to understand the course of infection of the parasite and also to investigate the 
haematological, immunological and serum biochemical changes if any during the infection that might lead to stress and affect the growth of fish.

\section{Materials and methods}

\section{Experimental design}

Results of earlier Investigations over a period of 3 years clearly showed that the gill fluke Paradactylogyrus catlaius of eastern India were more specific to catla and therefore catla were chosen as fish model for this experiment (Rana, 2015). Fifty numbers of apparently healthy juveniles of $C$. catla (average wt. 150 $\pm 10 \mathrm{~g}$ ) showing no signs of disease on gross morphological examination of skin and gills of representative samples, were obtained from the farm of ICAR-Central Institute of Freshwater Aquaculture (ICAR-CIFA), Bhubaneswar. Fish were acclimatised in 5001 plastic FRP tanks for 2 weeks prior to the experiment. They were fed with commercial pellet diet at $2 \%$ of their body weight. Fish showing active movements were used for short term infection studies. The water temperature in the tanks varied from $25-28^{\circ} \mathrm{C}$ during the experiment.

Thirty numbers of catla were randomly selected and kept in two separate tanks with 15 fish in each tank. In another tank, advanced fingerlings of catla infected with $P$. catlaius (confirmed by phase contrast microscopic examination of infected gill samples) collected from farmers pond, were maintained. Two heavily infected

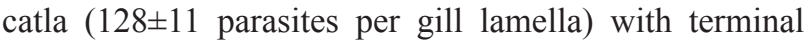
out in the caudal fin were introduced into the two experimental tanks for cohabitational challenge. Fishes were observed for a period of 20 days post-challenge. Fish from infected groups ( 3 fish from each group), from day 1 to day 20 post-challenge were sampled at 4 days interval. Before sampling the fish were anaesthetised with MS222 (Himedia Laboratories Pvt. Ltd. Mumbai, India) and bled non-lethally through the caudal vein using a sterile plastic $2 \mathrm{ml}$ syringe. Gill mucus samples were also collected for observation of parasite intensity per gill lamella. Blood and serum samples were examined for haematological [haemoglobin content, total erythrocyte count (TEC) and total leucocyte count (TLC)], immunological [nitroblue tertrazolium (NBT) assay, serum lysozyme activity and serum bactericidal activity] and serum biochemical parameters (total protein, albumin, globulin and albumin-globulin ratio). After every sampling, the fish were left back in separate tanks for healing.

\section{Haematological parameters}

Haemoglobin content $(\mathrm{Hb})$ was estimated by acid haematin method (Sahli, 1962) and was expressed as gram percentage. Total erythrocyte count (TEC) were estimated using Neubauer hemocytometer as described by Davidson and Henry (1969). TEC were calculated and reported as x $10^{6} \mathrm{~mm}^{-3}$ cells (Wintrobe, 1967). Total white blood cells or total leucocyte counts (TLC) were determined using Neubauer hemocytometer (Mgbenka et al. 2003) and reported as $\times 10^{3} \mathrm{~mm}^{-3}$ cells (Wintrobe, 1967).

\section{Non-specific immune parameters}

The NBT reduction assay was done following the protocol of Anderson and Siwicki (1995). Briefly, $0.1 \mathrm{ml}$ of heparinised blood was taken in eppendorf tube to which $0.1 \mathrm{ml}$ of $0.2 \%$ NBT (Sigma, USA) solution was added. The mixture was incubated for $30 \mathrm{~min}$ at $25^{\circ} \mathrm{C}$. From the resultant suspension, $50 \mu \mathrm{l}$ was taken, added to $1.0 \mathrm{ml} \mathrm{N}$, N-dimethyl formamide (DMF; Qualigens, Mumbai, India) in a glass tube and centrifuged at $3000 \mathrm{~g}$ for $5 \mathrm{~min}$. The optical density (OD) of the supernatant was measured at $540 \mathrm{~nm}$ in Bio-Rad Smart Spec ${ }^{\mathrm{TM}} 3000$. Turbidimetric assay for lysozyme was done according to Parry et al. (1965). Serum $(10 \mu \mathrm{l})$ was added to $1 \mathrm{ml}$ of Micrococcus luteus suspension, having $10^{7}$ cells at 0.5 O. D., incubated at $25^{\circ} \mathrm{C}$ and absorbance was measured at $530 \mathrm{~nm}$, from $0 \mathrm{~min}$ to $5 \mathrm{~min}$ at every $30 \mathrm{sec}$ interval using a spectrophotometer (Bio-Rad Smart $\mathrm{Spec}^{\mathrm{TM}} 3000$ ). A unit of lysozyme activity was defined as the amount of sample causing a decrease in absorbance of 0.001 per min. Serum bactericidal activity was analysed following the procedure of Kajita et al. (1990). An equal volume $(100 \mu \mathrm{l})$ of serum and bacterial suspension of Edwardsiella tarda were mixed and incubated for $1 \mathrm{~h}$ at $25^{\circ} \mathrm{C}$. Blank control was also prepared by replacing serum with sterile phosphate buffered saline (PBS). The mixture was then diluted with sterile PBS at a ratio 1:10. The serum-bacteria mixture $(100 \mu \mathrm{l})$ was plated onto nutrient agar and plates were incubated for $24 \mathrm{~h}$ at $37^{\circ} \mathrm{C}$. The number of viable bacteria was determined by counting the number of bacterial colonies developed.

\section{Serum biochemical parameters}

Serum samples were analysed for total protein following the method of Lowry et al. (1951) and albumin content as per Dumas et al. (1971). Globulin content was determined by subtracting albumin from total protein and then albumin:globulin $(\mathrm{A}: \mathrm{G})$ ratio was also estimated.

\section{Results and discussion}

During cohabitation, the parasite was found to take four days to infect healthy fish and on the fourth day the mean intensity of infection was $6 \pm 2$. During the subsequent sampling days, the intensity of infection was found to increase. The parasite number increased 27 times from day 4 to day 20 post-challenge and reached a mean intensity of $161 \pm 23$ (Fig. 1). 


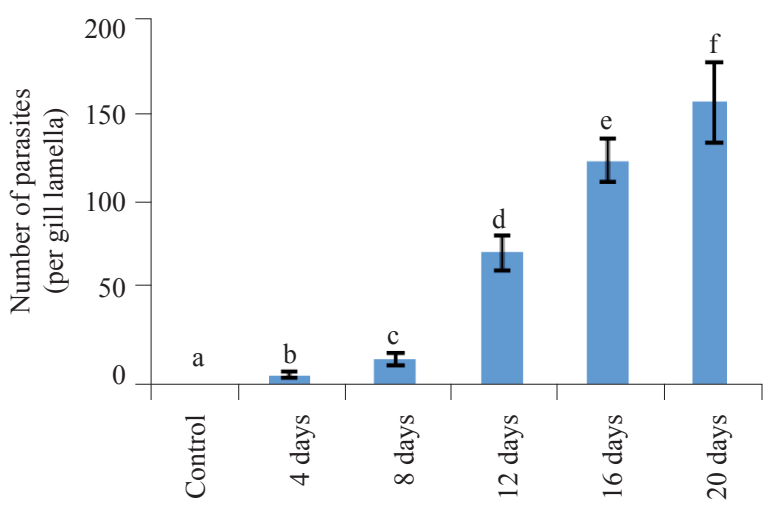

Fig. 1. Load of parasites on the gill of Catla catla over the experimental period of 20 days. * Data are expressed as mean \pm S.E. Means bearing common superscripts are not significantly different $(\mathrm{p}>0.05)$

Variation in $\mathrm{Hb} \%$ was significant $(\mathrm{p} \leq 0.05)$ from day 8 to day 20 post-challenge as compared to day zero. $\mathrm{Hb} \%$ was not significantly different between day 16 and day 20 post-challenge. However $\mathrm{Hb} \%$ reduced by $33 \%$ from day zero to day 20 (Fig. 2a). As the attachment of parasites increased, the TEC was found to reduce. The mean percentage of reduction in TEC was found to be $35 \%$ from day 1 post-challenge to day 20 (Fig. 2b). TLC increased significantly $(\mathrm{p} \leq 0.05)$ from day 8 to day 20 as compared to day zero of cohabitation. Initially up to day 4 the TLC increased insignificantly ( $p>0.05$ ) (Fig. 2c).

The results of NBT reduction assay showed that superoxide anion production increased up to day 12 and then found to decrease subsequently up to day 20 . The variation in superoxide anion production was significant $(p \leq 0.05)$ over the 20 days infection period except on day 4 . The highest superoxide anion activity was noticed on day 12 and lowest was on day zero (Fig. 3a). Up to day 4, the lysozyme activity insignificantly $(p>0.05)$ decreased as compared to day zero. However, lysozyme activity significantly $(\mathrm{p} \leq 0.05)$ reduced from day 8 to day 20 as compared to control. The lowest lysozyme activity was noticed on day 20 post-challenge (Fig. 3b). Bactericidal activity was significantly altered $(\mathrm{p} \leq 0.05)$ in comparison with the control group. Highest bactericidal activity was

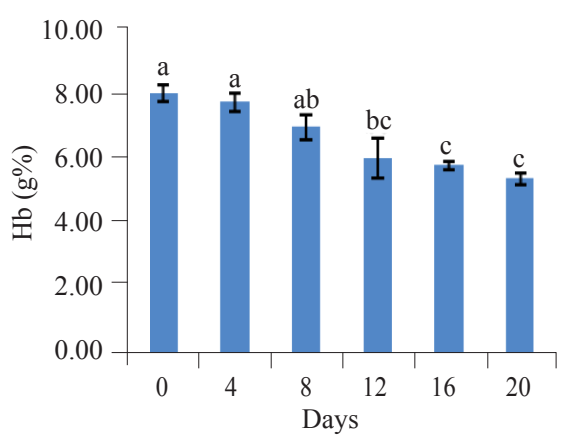

(a)

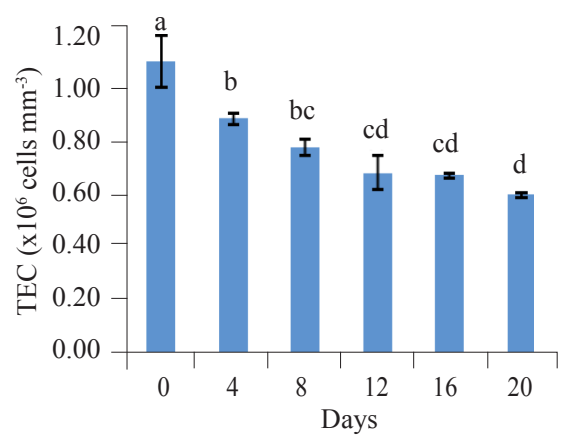

(b)

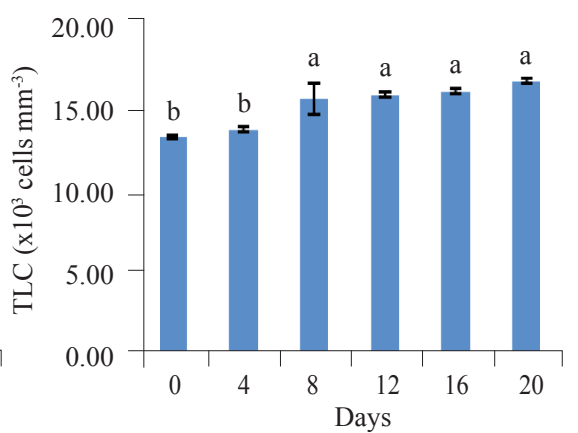

(c)

Fig. 2. Effect of P. catlaius on haematological parameters in C. catla over the experimental period of 20 days. (a) Haemoglobin content, (b) TEC, (c) TLC. "Data are expressed as Mean \pm S.E. Means bearing common superscripts are not significantly different $(\mathrm{p}>0.05)$

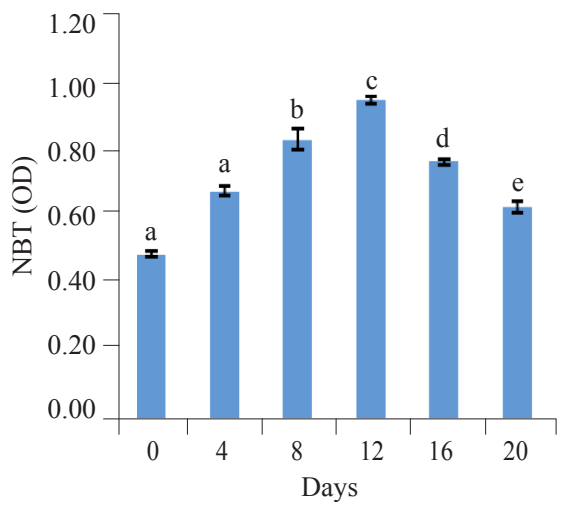

(a)

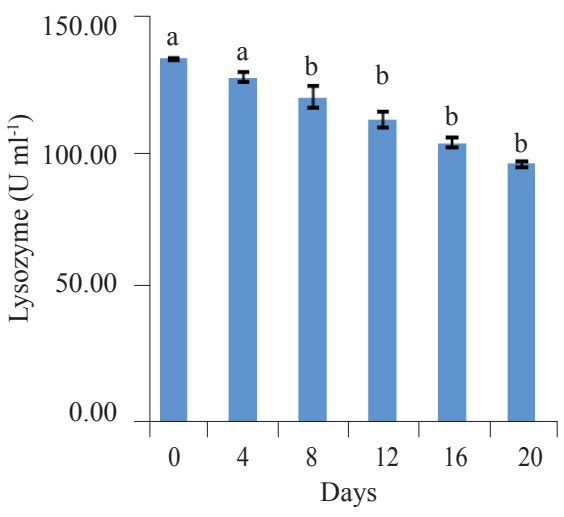

(b)

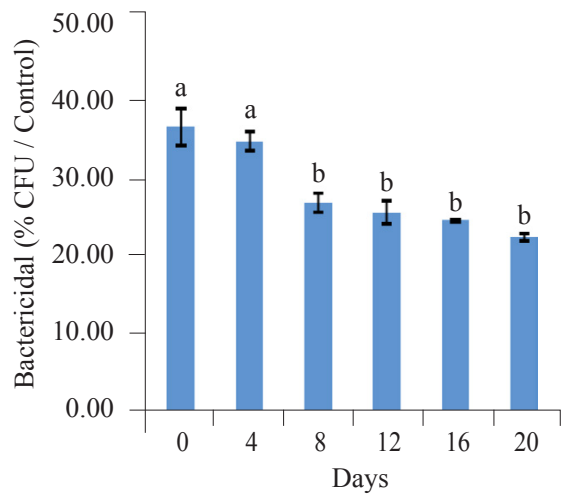

(c)

Fig. 3. Effect of P. catlaius on non-specific immune parameters in C. catla over the experimental period of 20 days. (a) NBT reduction, (b) Serum lysozyme activity, (c) Serum bactericidal activity. "Data are expressed as Mean \pm S.E. Means bearing common superscripts are not significantly different $(\mathrm{p}>0.05)$ 
noticed on day 8 and reduced up to day 20 post-challenge (Fig. 3c). As the infection proceeded, the serum total protein was found to reduce and the reduction was from day 12 onwards as compared to day zero of cohabitation. There was not much variation in the serum protein content ( $p>0.05$ ) within 8 days of infection (Fig. $4 a)$. The lowest serum protein content was observed on day 20 post-challenge.

A gradual significant $(p \leq 0.05)$ decrease in the total albumin content was observed up to day 20 from the day zero of challenge (Fig. 4b). The lowest albumin content was noticed on day 20. Serum globulin content was highest on day 8 as compared to day zero. However, a gradual and significant decrease in serum globulin $(\mathrm{p} \leq 0.05)$ was observed after day 8 of infection up to day 20 (Fig. 4c). A:G ratio was found to be significant on day 8 and day 20 of post-challengeas compared to day zero. On other days of assay A:G ratio was lower than that of day zero of cohabitation and it was below 1 (Fig. 4d).

In the present study, the number of parasites in host significantly increased from day 1 to day 20. Initially, as

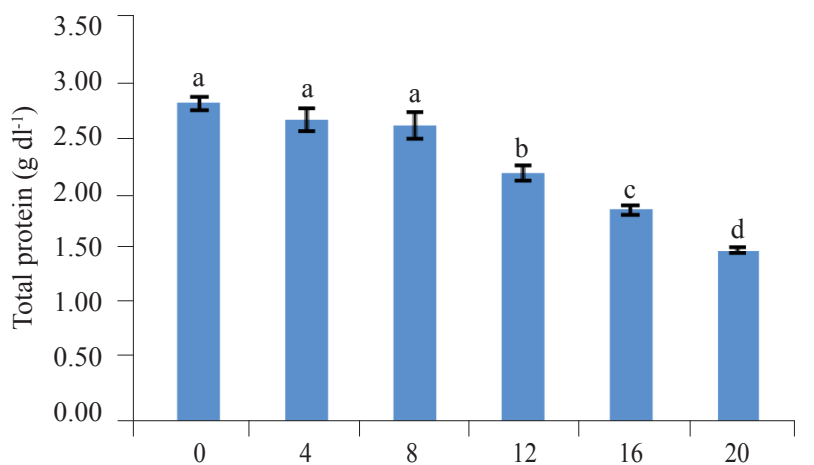

(a)

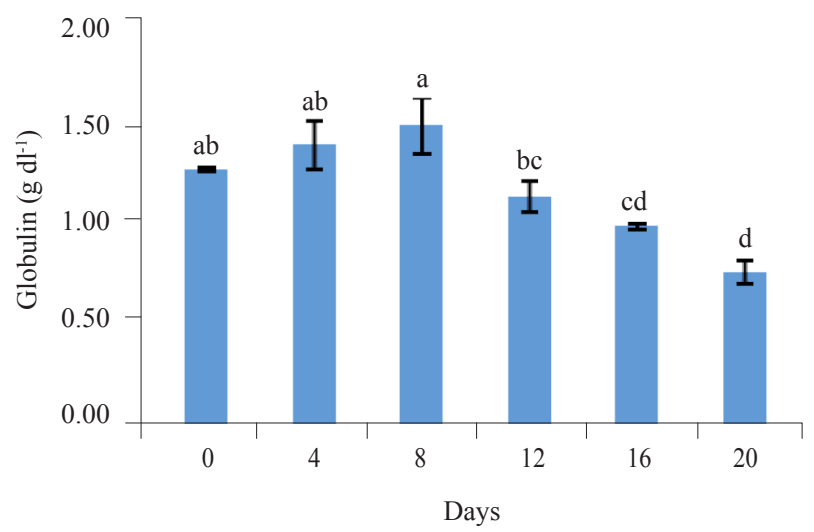

(c) the parasite intensity was less, differences in the haematological parameters, serum biochemistry and other immunological parameters were not found to vary much among the different groups of fish. Similar findings have been reported in four Brazilian teleost fish species with parasitic infection (Tavares-Dias et al., 2007), Mugil platanum with parasitic monogenean or copepod (RanzaniPalva et al., 1997); in Piaractus mesopotamicus with Argulus sp. (Tavares-Dias et al., 1999) and Oreochromis niloticus infected with Trichodina sp. and Lamprolegna sp. (Azevedo et al., 2006). From day 12 onwards, the intensity of infection of the parasite varied in individual fish, the variation was very high indicating the variations in the defense response of individual fish to fight against attachment and multiplication of parasites in individual gill lamella. Higher number of parasites indicates that the fish is unable to protect itself from the attachment of Paradactylogyrus which are easly prone to infection. The maximum number of parasites attached to one gill lamella had gone up to 184 within 20 days of post-challenge; indicating multiplication of the parasites within the host is prolific and rampant. As a measurable response to

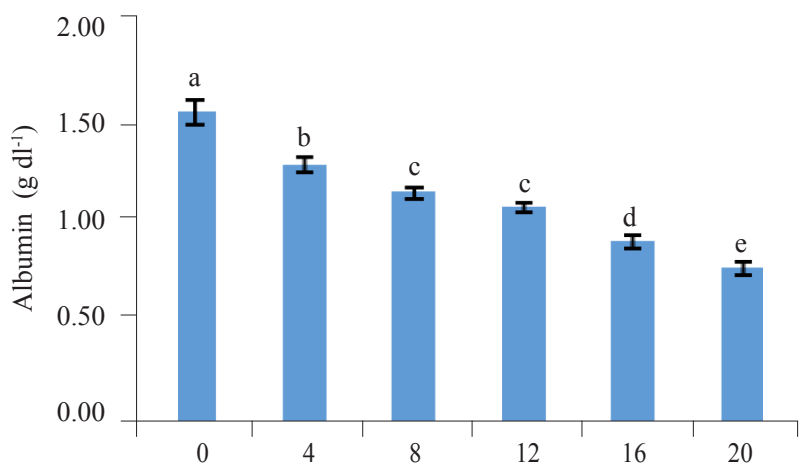

(b)

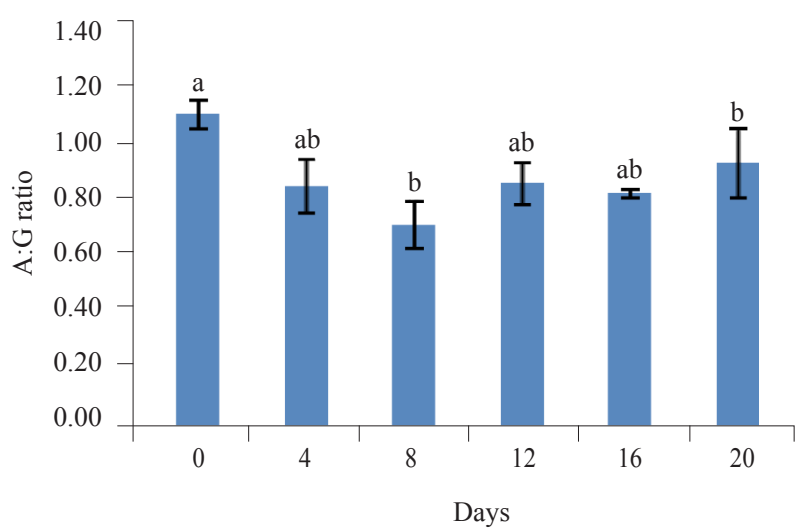

(d)

Fig. 8. Effect of P. catlaius on serum biochemical parameters in C. catla over the experimental period of 20 days. (a) Total protein content, (b) Total albumin content, (c) Total globulin content, (d) A:G ratio *Data are expressed as Mean \pm S.E. Means bearing common superscripts are not significantly different $(\mathrm{p}>0.05)$ 
the infection, haematological, serum biochemical and immunological parameters were recorded up to 20 days at 4 days interval. One of the important observation was that of the significant reduction of $\mathrm{Hb} \%$ in the blood of infected fishes which made the fish anaemic. finally leading to mortality. Absence of bleeding was noticed while dissecting fish of $>1 \mathrm{~kg}$ size, parasitised with P. catlaius indicating anaemic conditon of the fish. As the number of parasites increased, while dissecting fish of $>1 \mathrm{~kg}$ size, parasitised with $P$. catlaius the reduction in $\mathrm{Hb} \%$ was more pronounced. This indicates that the parasites mostly destroy the haemoglobin in fish and makes the fish anaemic.

Haider Ali and Ansari (2012) described the changes in hematological and biochemical indices in healthy and monogenean infected common carp. They noticed a significant decrease in hematological parameters like $\mathrm{Hb}$ and $\mathrm{RBC}$ and an increase in WBC count in monogenean infected common carp as compared to healthy Cyprinus carpio. Results of the present study also corroborates with the above results, as evidenced by reduction in $\mathrm{Hb} \%$, TEC and increase in TLC. Quality and quantity of leucocytes are generally used as indicators for determination of immune reactions and diseases (Cagirgan, 1990). A positive correlation between TLC and parasitic infection was observed during the study, i.e., TLC increased as intensity of infection increased to a certain extent. The TLC count was not significantly high until day 8 post-challenge. Neutrophils possessing phagocytic capability are often the first leucocytes to migrate to the site of parasitic infection (Silva-Souza et al., 2000). From the present blood parameter study in catla during short term infection with $P$. catlaius, TEC and $\mathrm{Hb}$ was found to reduce while TLC was found to increase, to certain extent during the same period, suggesting that the parasite is able to survive in the host in such condition.

The mechanism of specific immunity in fish is significantly less developed and plays a less important role than in birds and mammals. The fish have non-specific resistance system which plays a basic role in defense of the organism against pathogen (Pessan tino et al., 2005). The host innate immunity in response to the parasitic infection was measured in terms of NBT assay, lysozyme and bactericidal activity. NBT reduction activity increased significantly up to day 12 indicating that the production of superoxide anions by the leucocytes to combat the infection. So, initial increase of NBT activity could be attributed to oxidative mechanism for eliminating parasites in the host. Subsequently the NBT activity was found to gradually reduce and remained slightly high above that of the control group. Lysozyme is an active molecule for fish defense produced by phagocytes/neutrophils which prevents entry of bacterial pathogens by breaking glycocydic bonds of the peptidoglycan layer. In the present study, the lysozyme activity significantly decreased in the infected fishes as compared to the normal fish. Reduction in the lysozyme levels were earlier observed in Scopthalamus maximus (Sitja-bobadila et al., 2006) and Diplodus puntazzo infected with Enteromyxum leei (Alvajero- Pellitero et al., 2008). Reduction in lysozyme levels can be attributed to parasitic growth in the host. Bactericidal activity of serum was also significantly reduced from day 8 to day 20 . Total serum protein and albumin content reduced in the infected fishes during the short term infection study whereas globulin level was found to increase up to day 8 and subsequently reduced till day 20 . Similarly, A:G ratio also increased up to day 8 and then gradually reduced. The reduction in protein and albumin content could be attributed to parasitic infection which in turn could have blocked production of $\mathrm{Hb}$ and $\mathrm{RBC}$ as revealed by the results of the present study. During the initial phases of infection, the globulin content was not affected probably as the number of parasites per gill lamella was very low i.e., 4 - 7 and when it increased to $>20$, the globulin content was observed to be affected.

From the short term infection study of $P$. catlaius in catla, it was found that the parasite multiply rapidly in gill lamellae. Parasite infestation caused reduction in $\mathrm{Hb} \%$ and TEC in the blood, sufficient enough to make the fish anaemic. Further, reduction in the immunological parameters like serum lysozyme and bactericidal activity indicated immune suppression in infected fish. Results also indicated that in farming of catla, from the initial infection of $P$. catlaius, 20 days is sufficient enough to spread infection in the whole population and this can also lead to production loss. Therefore appropriate management strategies and control measures need to be undertaken to prevent spread of infection and reduce production loss.

\section{Acknowledgements}

The authors are thankful to the Director, ICARCIFA, Bhubaneswar for providing the necessary facilities to carry out the work.

\section{References}

Alvarez-Pellitero, P., Palenzuela, O. and Sitja-Bobadilla, A. 2008. Histopathology and cellular response in Enteromyxum leei (Myxozoa) infections of Diplodus puntazzo (Teleostei). Parasitol. Int., 57: 110-120.

Anderson, D. P. and Siwicki, A. K. 1995. Basic haematology and serology for fish health programs. In: Diseases in Asian aquaculture II. Shariff, M., Arthur, J. R. and Subasinghe, R. P. (Eds.), Fish Health Section, Asian Fisheries Society, Manila, Philippines, p. 185-202.

Azevedo, T. M. P., Martins, M. L., Bozzo, F. R. and Moraes, F. R. 2006. Hematological and gills response in parasitised 
tilapia from valley of Tijucas River, SC, Brazil. Scientia Agricola e uma publicaçao da Universidade de Sao Paulo, 63(2): $115-120$

Cagirgan, H. 1990. Immune system in teleost and its significance on diagnosis (in Turkish). Turk. J. Fish. Aquat. Sc., 7, 57-68.

Davidson, I. and Henry, J. B. 1969. Todd-Samford clinical diagnosis by laboratory method, $14^{\text {th }}$ edn. W. B. Saunders Co., Philadelphia, London, Toronto, p. 139-143.

Dumas, B. T., Watson, W. A. and Biggs, H. G. 1971. Albumin standards and the measurement of serum albumin with bromocresol green. Clinica Chimica Acta., 31: 87-96.

Haider, A. and Ansari, K. K. 2012. Comparison of haematologial and biochemical indices in healthy and monogenean infected common carp, Cyprinus carpio. Ann. Biol. Res., 3(4): 1843-1846.

Kajita, Y., Sakai, M., Atsuta, S. and Kobayash, M. 1990. The immunostimulatory effects of levamisole on rainbow trout, Oncorhnchus mykiss. Fish Pathol., 25(2): 93-98.

Kennedy, C. R. and Bush, A. O. 1994. The relationship between pattern and scale in parasite communities: a stranger in a strange land. Parasitol., 109: 187-197.

Lowry, O. H., Rosebrough, N. J., Farr, A. L. and Randall, R. J. 1951. Protein measurement with Folin phenol reagent. J. Biol. Chem., 193: 256.

Mgbenka, B. O., Oluah, N. S. and Umeike, I. 2003. Effect of gammalin 20 (Lindane) on differential white blood cell counts of the African catfish, Clarias albopunctatus. Environ. Contam. Tox., 71: 248-254.

Park, J. K., Kim, K. H., Kang, S., Kim, W., Eom, K. S. and Littlewood, D. T. J. 2007. A common origin of complex life cycles in parasitic flatworms: evidence from the complete mitochondrial genome of Microcotyle sebastis (Monogenea: Platyhelminthes). BMC Evol Biol., 7: 11.

Parry, R. M., Chandan, R. C. and Shahani, K. M. 1965. A rapid and sensitive assay of muramidase. P. Soc. Exp. Biol. Med., 119: 384-386

Passantino, L., Cianciotta, A., Patruno, R., Ribaud, M. R., Jirillo, E. and Passantino, G. F. 2005. Do fish thombocytes play an immunological role? Their cytoenzimatic profiles and function during an accidental piscine candidiasis in aquarium. Immunopharm. Immunotox., 27: 345-356.

Rana, N. and Das, B. K. 2014. Morphometric and molecular identification of Paradactylogyrus catlaius (Thapar 1948) in Catla catla (Hamilton 1822). J. Parasit. Dis., 40(1): $36-40$
Rana, N. 2015. Phenotypic and genotypic characterization of Dactylogyrus (Monogenea, Platyheminthes) infecting carps in Eastern India. Ph. D. Thesis, Utkal University, Odisha, India.

Ranzani-Paiva, M. J., Ishikawa, C. M., Campos, B. E. S. and Eiras, A. C. 1997. Hematological characteristics associated with parasitism in mullets, Mugil platanus Günther, from the estuarine region of Cananéia, São Paulo, Brazil. Rev. Bras. Zool., 14: 329-339.

Sahli, D. 1962. Determination of haemoglobin by acid haematin method. In: Dacie, J. V. and Lewis, S. M. (Eds.), Practical haematology, $5^{\text {th }}$ edn. Churuchill, London.

Sahoo, P. K. and Mukherjee, S. C. 2003. Immunomodulation by dietary vitamin $\mathrm{C}$ in healthy and aflatoxin B1-induced immunocompro mised rohu (Labeo rohita). Comp. Immunol. Microbiol. Infect. Dis., 26: 65-76.

Silva-Souza, A. T., Almeida, S. C. and Machado, P. M. 2000 Effect of the infestation by Lernaea cyprinacea Linnaeus, 1758 (Copedoda, Lernaeidae) on the leucocytes of Schizodon intermedius Garavello \& Britski, 1990 (Osteichthyes: Anostomidae). Rev. Bras. Biol., 60: 217-220.

Sitja-Bobadilla, A., Redondo, M. J., Bermudez, R., Palenzuela, O., Fereiro, I., Riaza, A., Quiroga, I., Nieto, J. M. and AlvarezPellitero, P. 2006. Innate and adaptive immune responses of turbot, Scophthalmus maximus (L.), following experimental infection with Enteromyxum scophthalmi (Myxosporea: Myzozoa). Fish Shellfish Immunol., 21: 485-500.

Tavares-Dias, M. and Moraes, F. R. 2007. Leukocyte and thrombocyte reference values for channel catfish (Ictalurus punctatus Raf.), with an assessment of morphological, cytochemical, and ultrastructural features. Vet. Clin. Pathol., 36: 49-54.

Tavares-Dias, M., Frasca-Scorvo, C. M. D., Moraes, F. R. and Campos-Filho, E. 1999. Haematological characteristics of Brazilian teleosts II. Blood parameters of Piaractus mesopotamicus Holmbery (Osteich, Characidae) in an intensive polyculture system. Revta Bras. Zool., 16(2): 423-431.

Thapar, G. S. 1948. A new monogenetic trematode from the gills of an Indian fish, Catla catla, from Lucknow. Indian $J$. Helminthol., 1(1): 1-10.

Wintrobe, M. M. 1967. Clinical hematology, $6^{\text {th }}$ edn. Library of Congress, Print, Lie and Febiger, Philadephia, USA.

Yamaguti, S. 1961. Systema helminthum, Monogenea and Aspidocotylea, vol. IV. Inter Science Publishers, New York, USA, 44 pp. 